\title{
ON THE CHOICE OF FLUID FOR THE HYDRATION OF MIDDLE-AGED MARATHON RUNNERS
}

\author{
T. KAVANAGH, M.D., D.Phys.Med., F.R.C.P.(C)* \\ and \\ R. J. SHEPHARD, M.D., Ph.D.† \\ *Toronto Rehabilitation Centre, 345 Rumsey Road, Toronto, Ontario. \\ tDepartment of Preventive Medicine \& Biostatistics, University of Toronto, Toronto, Ontario.
}

\begin{abstract}
Nine subjects (five well-trained post-coronary patients and four other middle-aged joggers) participated in a $42 \mathrm{~km}$. "Marathon" race. The course was covered in an average of 212 minutes under pleasantly warm conditions (Maximum $21.7^{\circ} \mathrm{C}, 69 \%$ relative humidity). Subjects were given initial hyperhydration and repeated subsequent doses of water, $\sigma^{\circ}$ "Erg" ( $\mathrm{Na}^{+} 19 \mathrm{mE} / \mathrm{l} \mathrm{K} \mathrm{K}^{+} 10.7 \mathrm{mE} / \mathrm{l}$, glucose $5.3 \mathrm{~g} / 100 \mathrm{ml}$ ) or a "Special Solution" (during the race $\mathrm{Na}^{+} 21 \mathrm{mE} / 1 \mathrm{glucose} \bigcirc$ $4.1 \mathrm{~g} / 100 \mathrm{ml}$; after the race $\mathrm{Na}^{+} 20 \mathrm{mE} / \mathrm{l}, \mathrm{K}^{+} 4.7 \mathrm{mE} / \mathrm{l}$., glucose $4.1 \mathrm{~g} / 100 \mathrm{ml}$ ). Weight loss averaged $2.2 \mathrm{~kg}$ and sweat $\rightarrow$ production 3.31 taking account of water liberated from the hydration of glycogen and the oxidation of food stuffs, it $\frac{D}{0}$ was estimated that most subjects suffered relatively little dehydration over the race $(0.4-0.81)$. This was confirmed by a sustained urine production of $>100 \mathrm{ml} / \mathrm{hr}$. Nevertheless, rectal temperatures showed substantial elevation over the $\vec{\varphi}$ race (final readings $38.3-40.2^{\circ} \mathrm{C}$ ). In terms of fluid balance and stability of plasma mineral composition, the runners drinking water performed slightly better than those receiving the other two solutions. Nevertheless, there may be merit in giving potassium solutions during recovery from vigorous effort.
\end{abstract}

\section{INTRODUCTION}

Dehydration of the marathon runner, well-recognized as a hazard for the young, top-level competitor (Wyndham \& Strydom, Costill, 1972), can develop to an almost equal extent in a middle-aged post-coronary patient who covers the same distance at a much slower pace (Kavanagh \& Shephard, 1974). However, a preliminary trial in the 1973 Hawaii Marathon (Kavanagh \& Shephard, 1975) suggested that as in laboratory exercise with younger subjects (Kozlowski \& Saltin, 1964), preliminary "super-hydration" and free access to fluids over the race were sufficient to sustain hydration throughout the $42 \mathrm{~km}$ event. Evidence supporting this view included (i) calculations of fluid balance, (ii) observation of continued urine secretion, and (iii) an increase of haematocrit relative to red cell count and haemoglobin levels (Costill et al, 1974).

Because of the distance from Toronto, only three of our post-coronary patients were able to participate in the Hawaii event, and the scope for scientific observations was also somewhat restricted. It was thus decided to organize a race over the marathon distance in the immediate environs of our laboratory. The objectives were to evaluate further the possibilities of sustaining body hydration in the middle-aged marathon runner, to study the evolution of the various physiological and biochemical variables, and to compare the merits of several possible replacement fluids.

\section{METHODS}

\section{Subjects and experimental plan}

Our subjects for the present experiment were five middle-aged patients seen $\mathbf{2 - 4}$ years after rehabilitation for myocardial infarction, and four healthy runners of similar age selected from the Metro Fitness Joggers Club. The physical characteristics of the two groups are summarized in Table I. There were no significant differences between the two groups, the five post-coronary patients being so completely rehabilitated that we were for practical purposes dealing with a homogenous and welltrained sample of middle-aged runners. Accordingly, data in subsequent tables is averaged without regard for clinical condition.

\section{TABLE I}

Physical characteristics of subjects (mean, S.D., range)

$\begin{array}{lll} & \text { "Post-Coronary" All } \\ \text { "Normals" } & \text { Patients } & \text { Subjects }\end{array}$

$\begin{array}{lrrr}\text { Age }(\mathrm{yr}) & 45.4 \pm 3.3 & 43.2 \pm 8.2 & 44.3 \pm 6.0 \\ \text { Height }(\mathrm{cm}) & 172.8 \pm 5.7 & 171.7 \pm 5.5 & 172.3 \pm 5.3 \\ \text { Weight }(\mathrm{kg}) & 65.6 \pm 3.3 & 67.0 \pm 4.4 & 66.3 \pm 3.8 \\ \text { Excess Weight (kg) } & -0.5 \pm 5.0 & +0.0 \pm 3.0 & -0.2 \pm 3.9 \\ \text { Aerobic power } & & & \\ \text { (1./min STPD) } & 3.41 \pm 0.50 & 2.99 \pm 0.41 & 3.18 \pm 0.50 \\ \text { (ml./kg.min STPD) } & 52.0 \pm 6.0 & 47.2 \pm 5.8 & 49.3 \pm 6.0\end{array}$


All subjects were given a full clinical and laboratory examination, including a sub-maximal bicycle ergometer prediction of maximum oxygen intake in the week preceding the race. The five "post-coronary" patients had also completed direct treadmill measurements of $\mathrm{VO}_{2}$ (max) previously, predictions made at that time agreeing well with the direct measurements. However, only two of the direct readings were obtained close to the timing of the laboratory race. The event was run for a four lap route of $42 \mathrm{Km}$, around roads in the vicinity of the Toronto Rehabilitation Centre. The runners set out at 8:30 a.m. on a pleasant June day; the air was almost still and a light haze reduced the radiant heat load. All competitors completed the race between 11:30 a.m. and $12: 30$ p.m. when the temperature had risen to $21.7^{\circ} \mathrm{C}$ with a relative humidity of $69 \%$.

Subjects were allocated to three treatment groups. Three runners (a Metro Jogger \& two post-coronary patients) were provided with the proprietary replacement fluid "Erg"* , four with our special fluids"* $(2$ Joggers and 2 post-coronary patients), while the remaining 2 subjects were allowed only water.

On arrival, subjects were required to drink $200 \mathrm{ml}$ of their allocated fluid, and to empty their bladders. Their clothing was weighed, and the subjects were then weighed wearing shorts, singlet, track shoes and socks. A further $200 \mathrm{ml}$ of the allocated fluid was offered to the runners at $2.6 \mathrm{~km}$ intervals, and a careful record of actual intake was kept. Weighings were repeated eight times over the course of the race, and after completion of the event the clothing was weighed wet.

Blood samples were collected from the median antecubital vein immediately before the race, at the half-way point, and immediately on crossing the finishing tape. The four subjects drinking the special fluids contributed a further sample of venous blood one hour after completion of the run. Blood specimens were analyzed for sodium, potassium and chloride ions, glucose, blood urea nitrogen, creatine and bicarbonate, and muscle enzymes (lactate dehydrogenase, creatine phosphokinase) using standard automated biochemical procedures.

\section{FOOTNOTES}

* "Erg" is a proprietary hyperosmolar solution recommended by its makers for marathon runners; analysis by the authors showed the composition $\mathrm{Na}^{+} 19 \mathrm{~m} \mathrm{Eq} / \mathrm{l} \mathrm{K}+10.7 \mathrm{~m} \mathrm{Eq/I}$, and glucose $5.3 \mathrm{~g} / 100 \mathrm{ml}(294 \mathrm{mEq} / \mathrm{l})$; total osmolarity is approximately $354 \mathrm{~m}$ Osmoles/l.

* The "special" fluid provided before and during the race was a glucose/chloride solution adjusted to be approximately isotonic with blood, containing $\mathrm{Na}^{+} 21 \mathrm{mEq} / \mathrm{l}$., and glucose $4.1 \mathrm{~g} / 100 \mathrm{ml}(228 \mathrm{mEq} / \mathrm{l})$; total osmolarity was approximately $270 \mathrm{~m}$ Osmoles/l. After the race, the mixture was modified to $\mathrm{Na}^{+} 20 \mathrm{mEq} / \mathrm{l} . \mathrm{K}^{+} 4.7 \mathrm{~m} \mathrm{Eq} / \mathrm{l}$, and glucose $4.1 \mathrm{~g} / 100 \mathrm{ml}$; totai osmolarity approx. $278 \mathrm{~m}$ Osmoles/l.
Blood pressures were measured immediately before and immediately after the event. Subjects were in the sitting position, and a standard clinical sphygmomano? meter cuff was used. Rectal temperatures were measured: by a clinical thermometer immediately after the race.

\section{RESULTS}

\section{Performance}

All subjects performed quite creditably, having regare़्द to their age and medical history (Table II). The average running time for the 9 subjects was $212 \mathrm{~min}$, corb responding approximately to a running speed of 12 $\mathrm{km} / \mathrm{hr}$. One of the Metro Joggers (L) showed some signf of vaso-vagal collapse after the event (pallor, sweating?. retching), but none of the post-coronary patients fely any ill-effects.

The final examination showed a small decrement of both systolic and diastolic blood pressures in all subjectso but none were grossly hypotensive. The final core tem? perature ranged quite widely from $100.4^{\circ} \mathrm{F}$ to $104.4^{\circ} \mathrm{F}$ $\left(38.0^{\circ} \mathrm{C}-40.2^{\circ} \mathrm{C}\right)$, with little difference between the groups receiving "Erg", "special" fluid, and water.

If the oxygen cost of running had been as found in treadmill experiments on younger men (Shephardp 1969), our subjects would have sustained an average of $86.5 \%$ of their maximum oxygen intake over the course of the race, even higher than figures for the Bostory Marathon (81\% - Kavanagh \& Shephard, 1974). How ever, running efficiencies were improved by the sus: tained jogging programme. Our data for the post? coronary patients showed an oxygen cost of treadmil? running averaging only $\mathbf{8 7 . 2 \%}$ of predictions from the Shephard nomogram. Dressendorfer \& Scaff (1975) havé also reported a road cost of $30 \mathrm{ml} . / \mathrm{kg} . \mathrm{min}$. for wello trained cardiac patients running at a speed of $8.4 \mathrm{~km} / \mathrm{hr} . \bar{\exists}$ $6 \%$ lower than predictions from the nomogram. Allows ing for this greater efficiency, our runners were opera: ting at $75.4 \%$ of their aerobic power, much as in younge? marathon contestants.

\section{Fluid Balance}

All subjects lost weight progressively over the course of the race despite a steady intake of fluid (Fig. 1). As inn the preliminary hyperhydration trial in Hawaii, the average loss of $2.2 \mathrm{Kg}$ (Table III) was much smaller tharp in Boston (average loss $4.0 \mathrm{Kg}$ ), this reflecting in part the initial hyperhydration $(0.20 \mathrm{l})$ and in part a muck greater fluid intake during the race (an average of 1.59 lo

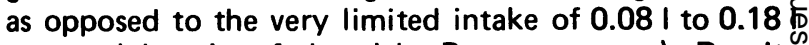
reported by six of the eight Boston runners). Despite more moderate environmental conditions, sweat loss (average $3.28 \mathrm{I}$ ) was only marginally less than in Bostor $(\sim 3.5 \mathrm{l})$. Hydration of the subjects participating in the present experiment was such that 7 of the 9 subjects were able to produce some urine over the course of the race. 


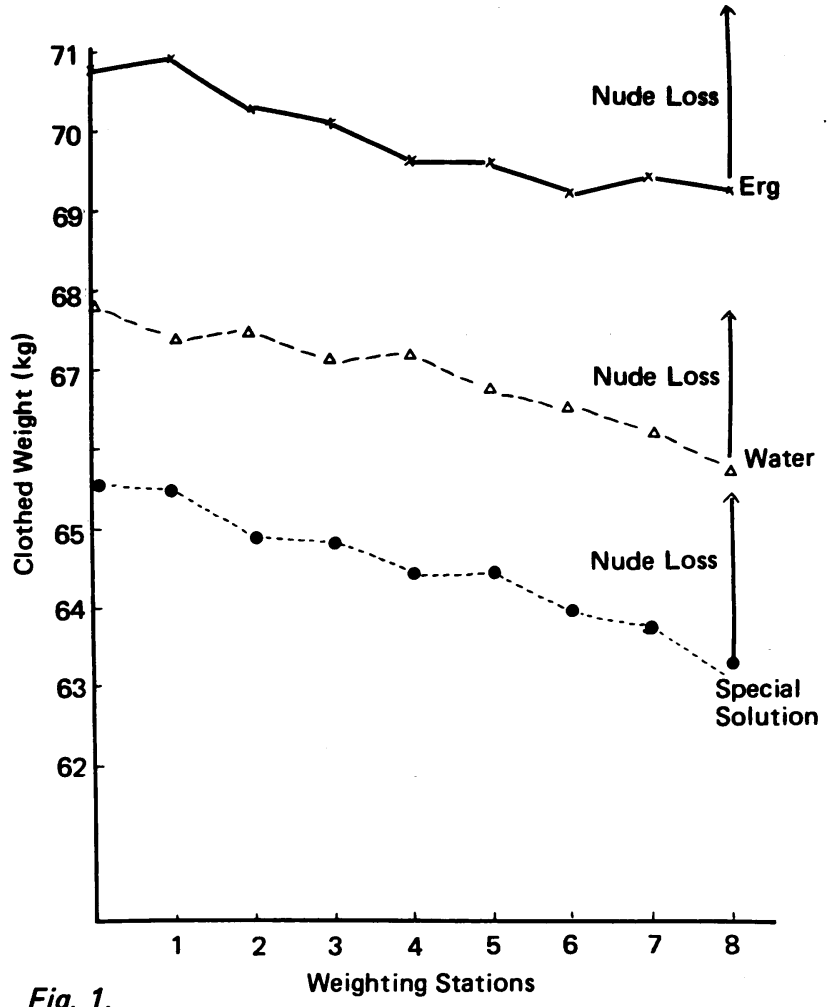

Cumulative Weight Loss over the Course of the Race.

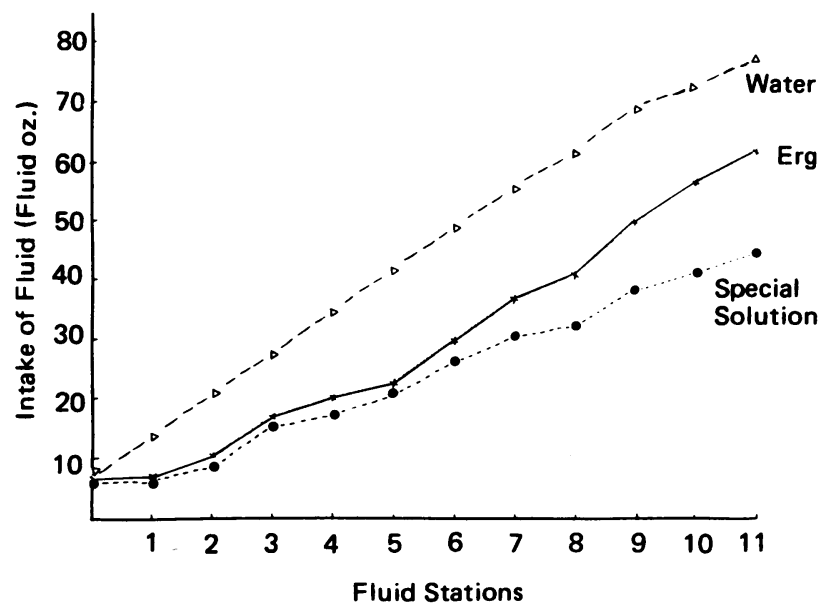

Fig. 2.

Cumulative Fluid Intake over the Course of the Race.

Comparison of the three fluids is complicated by inter-subject differences in the relative intensity of work and in the running speed. The subjects customarily drank "Erg", and the four allocated the "special" solu- tions found these rather bland in flavour. One of the two water drinkers (H.B.) complained that he felt much more exhausted in the final six miles than he had done in previous marathons where "Erg" was provided; however, his times were also better in the scientific marathon. In objective terms, the two water drinkers fared better than the other seven subjects, achieving the largest fluid intake (Fig. 2), the greatest urine formation, and the smallest weight loss (Table III). The highest rates of fluid intake (around $630 \mathrm{ml} / \mathrm{hr}$ ) were realized by one of the water drinkers and one of the "Erg" drinkers.

\section{Electrolyte Balance}

Irrespective of the replacement fluid provided, there was a small increase of plasma sodium over the course of the race (Table IV). This occurred mainly in the second half of the run, and was greatest in the 7 subjects drinking fluids containing sodium ions. Potassium ion concentrations also rose, particularly in the first half of the race; the gain was no larger in subjects drinking the potassium fortified solution ("Erg") - indeed, the largest increments occurred in the two water drinkers. One hour after the race, blood potassium levels were depressed despite rehydration with the second special (potassium fortified) solutions.

Chloride ion concentrations increased slightly in the groups drinking "Erg" and the special solutions, but showed a slight drop in the two subjects who drank water.

\section{Metabolites}

Blood glucose readings increased over the first half of the race, and thereafter remained constant or showed a small decrease. Blood sugar readings were better sustained in the two runners who drank water than in the 7 who were given glucose-fortified solutions.

As in the Boston and Hawaii studies, blood urea rose over the race, with rather uniform increments in the two halves of the event. The largest increase was in the two subjects given the glucose-free solution; it is tempting to interpret this as indicating that these two subjects placed a greater reliance upon protein catabolism, but on the other hand, they showed a smaller increase of serum creatine than the other groups.

Blood lactates were not determined, but the occurrence of some anaerobic metabolism in all subjects may be inferred from the decrease of serum bicarbonate over the course of the race.

\section{Serum Enzymes}

All subjects showed a substantial increase of serum enzymes. This developed progressively over the course of the race (Table VI). The large change of lactate dehydrogenase in the two subjects receiving water may reflect an intense relative effort on their part. 
TABLE /

Aerobic Power and Performance of Subjects in Marathon Event

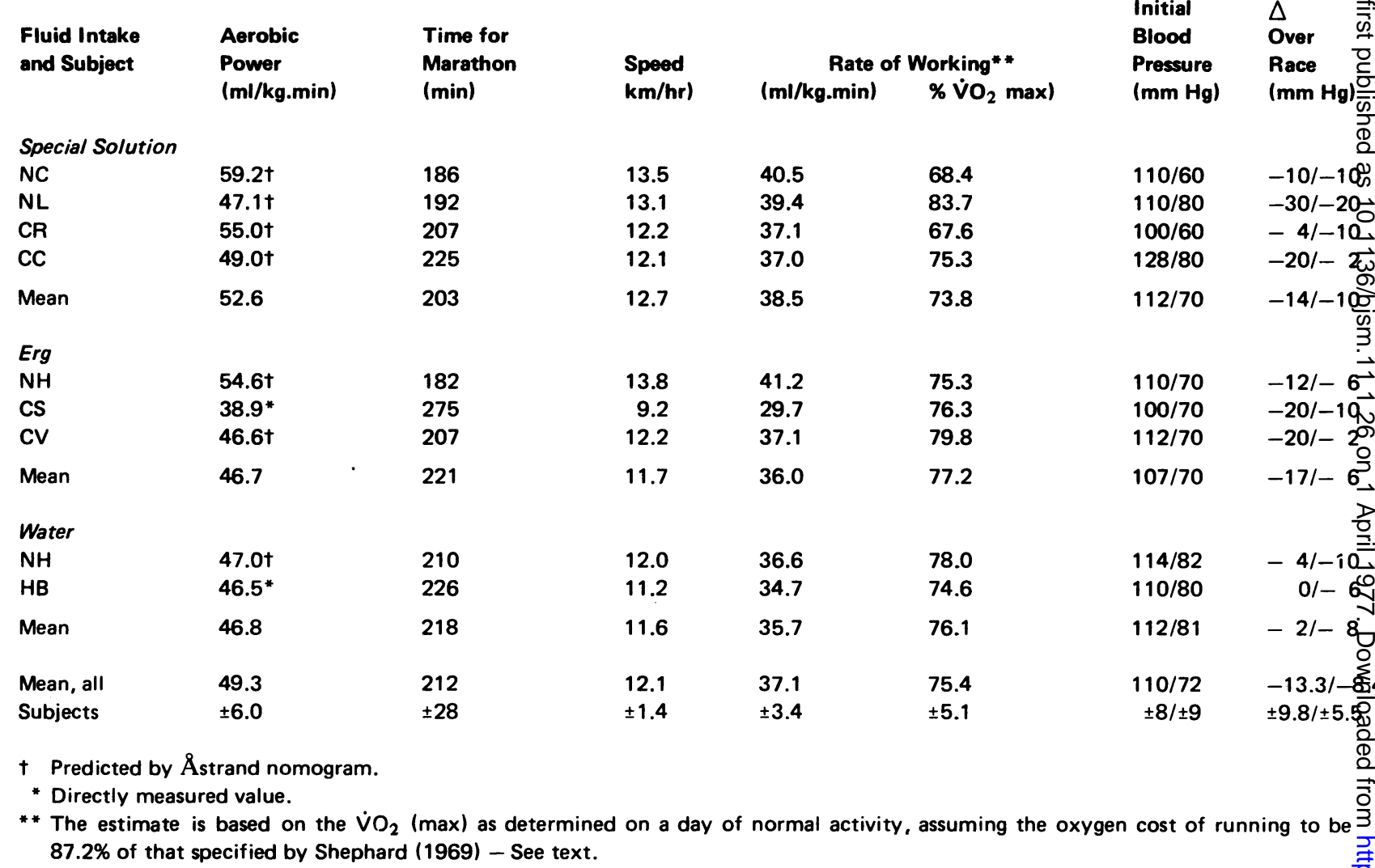

\section{DISCUSSION}

Hydration Although the body weight loss averaged 2.2 $\mathrm{kg}$, it seems likely that there was little tissue dehydration. Indeed, the majority of subjects matched their normal daytime urine secretion of $\sim 100 \mathrm{ml} / \mathrm{hr}$, although much of this urine may have been formed in the early stages of the race, when the runners were still substantially hyperhydrated.

The method of estimating fluid balance has been discussed previously (Åstrand \& Saltin, 1964; Kavanagh $\&$ Shephard, 1974). The total energy cost of the race is around $3700 \mathrm{Kcal}$; this is met by conversion of about $0.5 \mathrm{~kg}$ of foodstuffs into $0.3 \mathrm{~kg}$ of water and $0.73 \mathrm{~kg}$ of carbon dioxide. Much of the energy is derived initially from glycogen $(400 \mathrm{~g}$ are stored within muscle fibres, $100 \mathrm{~g}$ within the liver); it is clear from the final blood sugar figures that not all of these reserves are exhausted over a race, but if $70 \%(350 \mathrm{~g})$ were used by the water drinking runners, a substantial water of hydration $13 \mathrm{~g} / \mathrm{g}$, $1.05 \mathrm{~kg}$ of water) would become available to the tissues.
The true status of the water drinking subjects could thus be presented as follows:

(1) Average weight loss

(2) Weight loss due to oxidation of food

$1.95 \mathrm{~kg}$

(3) Weight loss due to sweat evaporation (1-2)

(4) Water gained from oxidation of food

(5) Water gained from breakdown of glycogen

(6) Net dehydration $(3-[4+5])=$

(7) Water intake

(8) Urine secretion

(9) Net fluid intake (7-8) =

(10 Total sweat secretion $(3+9)=$

$0.20 \mathrm{~kg}$

$1.75 \mathrm{~kg}$

$0.30 \mathrm{~kg}$

$1.05 \mathrm{~kg}$

$0.40 \mathrm{~kg}$

2.19 litres

0.50 litres

1.69 litresco

3.44 litres

Because of water liberated from glycogen molecules it is likely that the water drinkers sustained a substantia ${ }^{+}$ weight loss without appreciable dehydration; indeed, if all of their glycogen reserves had been used, they coulof even have become hyperhydrated.

Under resting conditions, Hunt \& Pathak (1960) and Hunt (1961) have noted that gastric emptying proceedso 
TABLE III

Fluid Balance over the Course of the Marathon Race

\begin{tabular}{|c|c|c|c|c|c|c|c|c|c|c|c|c|}
\hline \multirow{3}{*}{$\begin{array}{l}\text { Fluid } \\
\text { Intake \& } \\
\text { Subject }\end{array}$} & \multirow{2}{*}{\multicolumn{2}{|c|}{ Body Weight }} & \multirow{2}{*}{\multicolumn{2}{|c|}{ Weight Loss }} & \multirow{3}{*}{$\begin{array}{l}\text { Fluid } \\
\text { Intake } \\
\text { I }\end{array}$} & \multirow{3}{*}{$\begin{array}{l}\text { Urine } \\
\text { Loss } \\
1\end{array}$} & \multirow{3}{*}{$\begin{array}{l}\text { Food } \\
\text { Loss } \\
\mathbf{K g}\end{array}$} & \multirow{3}{*}{$\begin{array}{l}\text { Sweat* } \\
\text { Loss } \\
1\end{array}$} & \multicolumn{3}{|c|}{ Rectal Temperature } & \multirow{3}{*}{$\begin{array}{l}\text { Poten } \\
\text { Dehy } \\
\text { I }\end{array}$} \\
\hline & & & & & & & & & Initial & Final & $\Delta$ & \\
\hline & Initial & Final & $\mathbf{K g}$ & $\%$ & & & & & ${ }^{\circ} \mathrm{C}$ & ${ }^{\circ} \mathrm{C}$ & ${ }^{\circ} \mathrm{C}$ & \\
\hline \multicolumn{13}{|c|}{ Special Solution } \\
\hline NC & 68.0 & 65.8 & -2.2 & & 1.40 & 0 & 0.2 & 3.40 & 36.7 & 38.6 & 1.9 & \\
\hline NL & 60.9 & 58.4 & -2.5 & & 0.82 & 0 & 0.2 & 3.12 & 36.4 & 39.0 & 2.6 & \\
\hline CR & 62.1 & 59.6 & -2.5 & & 1.03 & 0.53 & 0.2 & 2.80 & 37.4 & 39.7 & 2.3 & \\
\hline $\mathrm{CC}$ & 66.7 & 64.9 & -1.8 & & 1.73 & 0.62 & 0.2 & 2.71 & 37.2 & 39.3 & 2.1 & \\
\hline \multicolumn{13}{|l|}{ Mean for } \\
\hline Group & 64.4 & 62.2 & -2.25 & & 1.25 & 0.29 & 0.2 & 3.01 & 36.9 & 39.2 & 2.3 & 0.70 \\
\hline \multicolumn{13}{|l|}{ Erg } \\
\hline NH & 66.5 & 64.3 & -2.2 & & 1.39 & 0.51 & 0.2 & 2.88 & 37.4 & 38.3 & 0.9 & \\
\hline CS & 74.4 & 72.3 & -2.1 & & 2.28 & 0.23 & 0.2 & 3.95 & 36.7 & 40.0 & 3.3 & \\
\hline CV & 68.5 & 65.8 & -2.7 & & 1.50 & 0.23 & 0.2 & 3.77 & 36.7 & 40.2 & 3.5 & \\
\hline \multicolumn{13}{|l|}{ Mean for } \\
\hline Group & 69.8 & 67.5 & -2.33 & & 1.72 & 0.32 & 0.2 & 3.53 & 36.9 & 39.5 & 2.6 & 0.78 \\
\hline \multicolumn{13}{|l|}{ Water } \\
\hline NH & 69.4 & 67.6 & -1.8 & & 2.29 & 0.52 & 0.2 & 3.37 & 36.9 & 39.4 & 2.5 & \\
\hline CB & 64.2 & 62.1 & -2.1 & & 2.07 & 0.48 & 0.2 & 3.49 & 36.6 & 39.0 & 2.4 & \\
\hline \multicolumn{13}{|l|}{ Mean for } \\
\hline Group & 66.8 & 64.9 & -1.95 & & 2.18 & 0.50 & 0.2 & 3.43 & 36.7 & 39.2 & 2.5 & 0.40 \\
\hline \multicolumn{13}{|l|}{ Mean \pm} \\
\hline S.D. all & 66.7 & 64.5 & -2.22 & & 1.59 & 0.35 & 0.2 & 3.26 & 36.9 & 39.3 & 2.39 & 0.67 \\
\hline Subjects & \pm 4.1 & \pm 4.2 & \pm 0.30 & & \pm 0.52 & \pm 0.24 & & \pm 0.43 & \pm 0.36 & \pm 0.63 & \pm 0.7 & \\
\hline
\end{tabular}

* This is approximated by the sum of (weight loss + fluid intake) - (urine loss + food loss).

* This is approximated by (sweat loss + urine loss) - (fluid intake + 1.35 I metabolic water).

most rapidly following ingestion of saline solutions having an osmolarity of approximately $250 \mathrm{mO} / \mathrm{l}$. In their experiments, both potassium ions and glucose molecules slowed emptying relative to pure water. Hunt explained his findings in terms of a hypothetical pyloric or duodenal osmoreceptor, shrinking when water absorption was restricted by strong glucose solutions, and expanding when penetrated by sodium ions and associated water. It is uncertain how far his hypothesis can be extrapolated to the marathon runner. Hunt's subjects ingested a single, relatively large volume of fluid (750 $\mathrm{ml}$ ), thus ruling out the possibility of adjustments in tonicity by gastric secretion. Further, most authors have found that vigorous exercise modifies normal patterns of gastric emptying (Campbell et al, 1928; Hellebrandt \& Tepper, 1934; Fordtran \& Saltin, 1967). The fastest fluid intake attained by our subjects (about 630 $\mathrm{ml} /$ hour) was slightly less than the figure of $800-1000$ $\mathrm{ml} /$ hour previously reported by Costill (1972). His subjects were younger, and his experiment was conducted in the laboratory; runners were required to drink $100 \mathrm{ml}$ every 5 minutes to the point of gastric distention, and he comments it was unlikely that further fluid could have been imbibed beyond the 100 minute experiment; in contrast, our subjects continued to take in fluid throughout the race. The total fluid intake ( $\sim 2$ litres) was similar in Costill's experiment and in ours. Likewise, our data agree with his in showing marginally more absorption of water than of solutions containing $4 \mathrm{~g}-5 \mathrm{~g}$ glucose $/ 100 \mathrm{ml}$. This does not seem a reflection of palatability - indeed, when given a free choice, the majority of our runners selected the "Erg", the likely basis is the osmolarity of the mixture.

The possible merit of more dilute glucose solutions $(2-3 \mathrm{~g} / 100 \mathrm{ml})$ remains debatable. It is possible that the negative impact of such concentrations on gastric emptying can be offset by low concentrations of sodium ions. However, the glucose content contributes little caloric support to the runner. Even if the entire imbibed dose (perhaps $50 \mathrm{~g}$ with 2 litres of $2.5 \%$ glucose) were metabolized, the caloric yield $(<200 \mathrm{~K} \mathrm{Cal})$ would be of 


\section{TABLE IV}

Changes in blood electrolytes over course of marathon race. Samples obtained (1) immediately prior to race, (2) mid-point, (3) immediately after race, and (4) one hour later.

Fluid Intake

and subject

( $N=$ "normal",

C=post-coronary)

$\mathrm{Na}^{+}$(mE/I.)

$K^{+}(\mathrm{mE} / \mathrm{I})$

$\mathrm{Ct}^{\prime}$ (mE/I.)

\begin{tabular}{|c|c|c|c|c|c|c|c|c|c|c|}
\hline & (1) & (2) & (3) & $\begin{array}{l}\Delta \\
1 \rightarrow 3\end{array}$ & (4) & (1) & (2) & (3) & ${\underset{1 \rightarrow 3}{\Delta}}_{1 \rightarrow 3}$ & (4) \\
\hline \multicolumn{11}{|l|}{ Special Solution } \\
\hline NC & 149 & 146 & 150 & +1.0 & 149 & 4.4 & 4.7 & 5.0 & +0.6 & 4.1 \\
\hline NL & 143 & 146 & 148 & +5.0 & - & 5.0 & 4.9 & 5.0 & 0.0 & - \\
\hline CR & 145 & 145 & 147 & +2.0 & 147 & 5.8 & 5.1 & 6.1 & +0.3 & 4.5 \\
\hline CC & 144 & 146 & 148 & +4.0 & 146 & 4.7 & 4.8 & 5.1 & +0.4 & 4.5 \\
\hline Mean & 145.3 & 145.8 & 148.3 & +3.0 & 147.3 & 5.0 & 4.9 & 5.3 & +0.3 & 4.4 \\
\hline \multicolumn{11}{|l|}{ Erg } \\
\hline NH & 145 & 147 & 148 & +3.0 & - & 4.2 & 4.8 & 4.6 & +0.4 & - \\
\hline CS & 149 & 147 & 149 & 0.0 & - & 5.0 & 5.0 & 5.1 & +0.1 & - \\
\hline CV & 147 & 144 & 150 & +3.0 & - & 4.0 & 4.7 & 4.7 & +0.7 & - \\
\hline Mean & 147.0 & 146.0 & 149.0 & +2.0 & - & 4.4 & 4.9 & 4.8 & +0.4 & - \\
\hline \multicolumn{11}{|l|}{ Water } \\
\hline NH & 145 & 144 & 145 & +0.0 & - & 4.6 & 5.5 & 5.4 & +0.8 & - \\
\hline $\mathrm{CB}$ & 144 & 145 & 147 & +3.0 & - & 4.7 & 5.0 & 5.1 & +0.4 & - \\
\hline Mean & 144.5 & 144.5 & 146.0 & +1.5 & - & 4.7 & 5.3 & 5.3 & +0.6 & - \\
\hline Mean all subjects & 145.6 & 145.6 & 148.1 & 2.5 & & 4.71 & 4.94 & 5.12 & 0.41 & \\
\hline D. & \pm 2.2 & \pm 1.1 & \pm 1.5 & \pm 1.7 & & \pm 0.53 & \pm 0.25 & \pm 0.44 & \pm 0.26 & \\
\hline
\end{tabular}

S.D.

(1)

(2)

(3)

$\operatorname{lis}_{1 \rightarrow 3}$

(4)

$\begin{array}{llll}103 & 103 & 104+1.010 \%\end{array}$

$\begin{array}{lllll}102 & 104 & 105 & +3.0 & 3\end{array}$

$\begin{array}{lllll}105 & 106 & 105 & 0.0 & 105\end{array}$

$\begin{array}{lllll}106 & 108 & 106 & 0.0 & 105\end{array}$

$104.0105 .3105 .0+1.0104$

$\begin{array}{lllll}104 & 106 & 105 & +1.0 & \text { 竎 } \\ 105 & 106 & 107 & +2.0 & \text { ․․ } \\ 100 & 102 & 107 & +7.0 & \text { च } \\ 103.0 & 104.7 & 106.3 & +3.3 & - \text { V }\end{array}$

$\begin{array}{llll}104 & 104 & 103 & -1.0\end{array}$

$\begin{array}{llll}105 & 105 & 103 & -2.0\end{array}$

$104.5104 .5103 .0-1.5$

$103.8104 .9105 .0 \quad 1.2$

$\pm 1.9 \pm 1.8 \pm 1.5 \pm 2.6$ minor importance. It might serve to spare an equivalent quantity of glycogen, but at the same time the body would be denied the $150 \mathrm{ml}$ water of hydration that otherwise would have been liberated from the glycogen. It is furthermore uncertain that the active muscle fibres can absorb glucose from the blood stream when exercising at marathon intensities $>75 \%$ of aerobic power). While Bagby \& Gollnick (1975) argue that blood-borne glucose makes a substantial contribution to metabolism in the vigorously exercising rat, others (Van Handel et al, $1975)$ have found as little as $2 \%$ of dilute $(2.5 \mathrm{~g} / 100 \mathrm{ml})$ glucose solutions are absorbed and oxidized in the third hour of quite modest effort ( $\sim 50 \%$ of aerobic power). Presumably, there are circumstances where high intracellular concentrations of glucose-6-phosphate together with blood-borne catecholamines are sufficient to inhibit the hexokinase activity of the muscle cell membrane.

Despite relatively pleasant weather conditions and vigorous efforts at sustaining body hydration, the majority of the runners showed a substantial elevation of core temperature over the course of the race. Further- more, there were no great differences of temperature between well-hydrated and less well-hydrated runners. In a competitive situation, it would seem that the thermad advantages of more complete hydration can easily be dissipated by running at a slightly faster pace.

Electrolytes Several imponderables limit the precision of electrolyte balance sheets - we do not know the precise ionic loss in either sweat or urine, nor do we know the extent of any exchange of metallic ions between tho normal "sodium space' and intracellular fluids. It is a little surprising that sodium ion concentrations rise in the water drinkers, since they are but little dehydrated and each litre of sweat replaced by water robs the body of some $30 \mathrm{mE}$ of sodium ions. Whatever the explana@ tion, it implies that it is unnecessary and even un 0 desirable to incorporate sodium ions into fluids ade ministered during a race. In our experiments, the "Erg ${ }^{\text {कब्ठ }}$ drinkers received some $39 \mathrm{mE}$ of $\mathrm{Na}^{+}$, and the specia席 solution drinkers $32 \mathrm{mE}$ of $\mathrm{Na}^{+}$; in consequence, theif final plasma composition was $1.0-1.5 \mathrm{mEq} / \mathrm{l}$ more abnormal than that of the men drinking pure water. 
$\Xi$
8
$\frac{5}{8}$

ङ ఖ

ह

มี จ

ฐ

ริ

हึ

ฐ ญ

2

ฐ

感

S

ป స్తు

2

ठ के

.ับ

है

ฐ.

ำ

เ

ญั

ठे

$2 . \frac{1}{2}$

ठัญ

ธัธ

ชิ

웛

.

\%

ถั

डे ญे

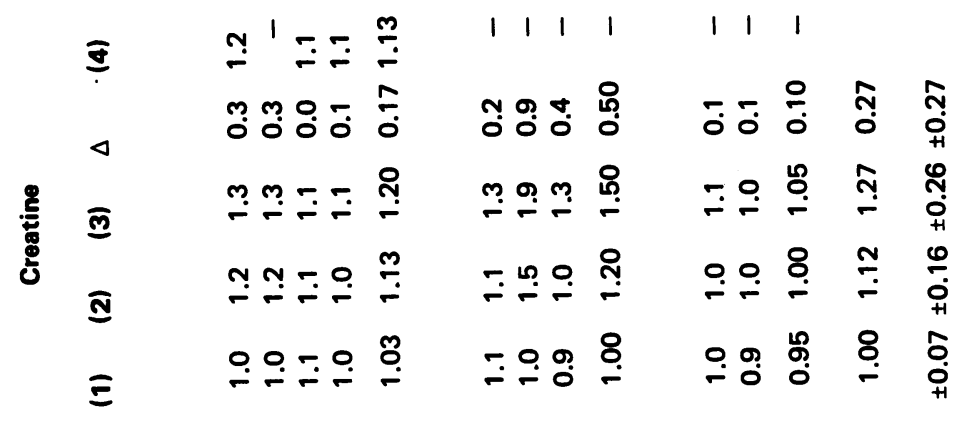

ฮ

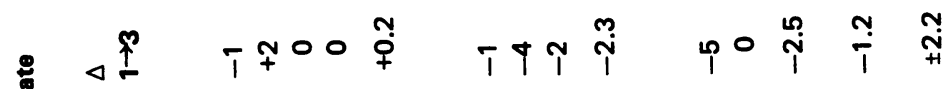

商 $\quad$ ก

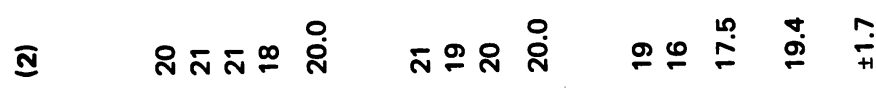

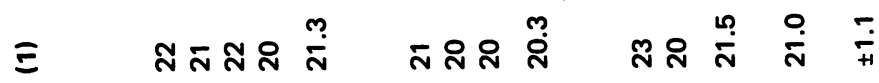

ฮ

\)

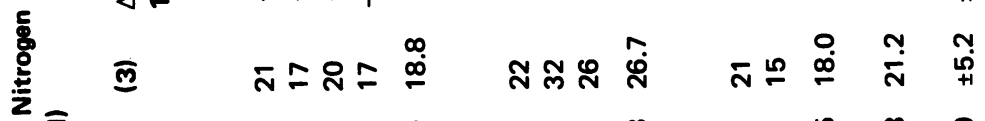

गั้

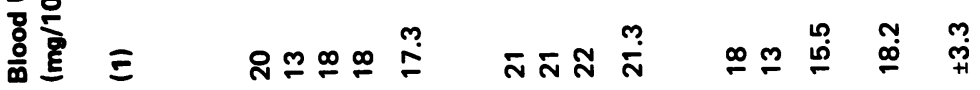

ఫ $\quad$

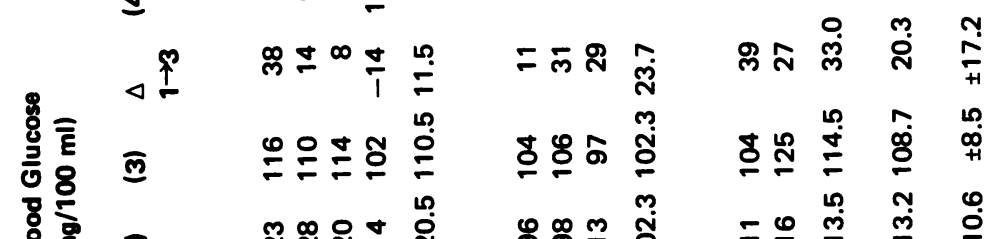

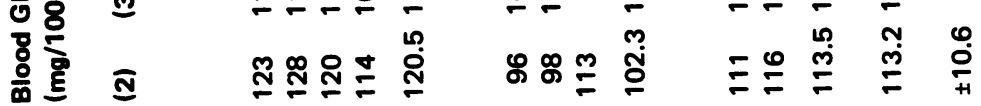

E $\quad$ 용요

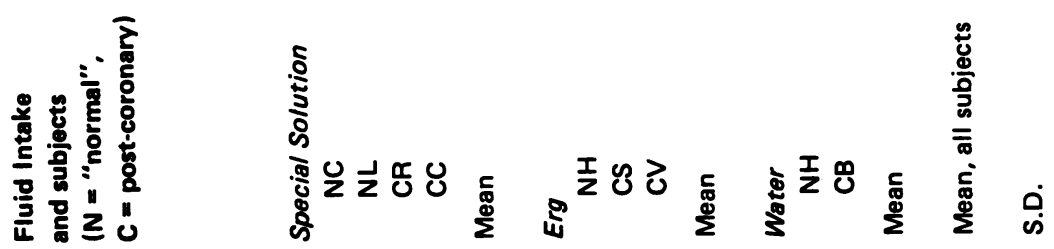


TABLE VI

Elevation of lactic dehydrogenase and creatine phosphokinase over the course of the marathon. Samples obtained (\$) before the race, (2) at the mid-point, (3) at the end of the race, and (4) one hour later

Fluid Intake

and subject

I $=$ "normal",

C = post-coronary)

\author{
Lactic dehydrogenase \\ Units/100 ml
}

(4)

Special Solution
NC
NL
CR
CC

Mean

Erg

$\begin{array}{llllll}\text { NH } & 173 & 199 & 217 & 44 & - \\ \text { CS } & 118 & 152 & 182 & 64 & - \\ \text { CV } & 130 & 154 & 184 & 54 & - \\ \text { Mean } & 140.0 & 168.0 & 194.0 & 54.0 & - \\ & & & & & - \\ \begin{array}{l}\text { Water } \\ \quad \text { NH } \\ \text { CB }\end{array} & 166 & 194 & 257 & 91 & - \\ \text { Mean } & 133 & 186 & 279 & 146 & - \\ \text { Mean, all subjects } & 138.8 & 170.4 & 207.0 & 69.1 & \\ \text { S } & 149.5 & 190.0 & 268.0 & 118.5 & \\ \text { S.D. } & & & & & \end{array}$

The increase of serum $\mathrm{K}^{+}$concentrations over the race reflects a steady ionic leakage from heavily exerted and hypoxic muscle fibres; again, the phenomenon is shown by the water drinkers, and it would thus seem inappropriate to administer potassium ions during a race. The practice would have a little more theoretical justification in the recovery period, when muscle potassium stores are being replenished, although even at this stage, it is difficult to show a specific advantage in subjects receiving potassium fortified solutions (Costill, 1975). The "Erg" solution provided our runners with approximately $21 \mathrm{mE}$ of potassium ions over the course of the race, and it is surprising that this group of subjects did not show a greater elevation of potassium levels than those those drinking water or the special solution. Possibly the unwanted potassium ions were not absorbed from the gut. A second factor is that the water-drinkers put forth a greater effort relative to their aerobic powers. Some authors have linked potassium leakage with glycogen depletion (Fenn, 1939); however, the present difference can hardly be ascribed to the glucose content of the ingested fluids, since there was little difference of blood sugar levels between the three groups of subjects.

\section{Creatine phosphokinase Units/100 ml}

(1)

4
3
5
4
4.0

(3)

$\Delta$

(4)

$\begin{array}{lc}6 & 9 \\ 4 & 6 \\ 8 & 11 \\ 6 & 8 \\ 6.0 & 8.5\end{array}$

5
3
6
4

4.5

10
8
12
8
9.5

-
-
-
-
-
-
-

$\begin{array}{lllll}6 & 8 & 12 & 6 & - \\ 4 & 6 & 8 & 4 & - \\ 3 & 4 & 6 & 3 & - \\ 4.3 & 6.0 & 8.7 & 4.4 & -\end{array}$

The chloride figures for the two water drinkers show a slight fall. Factors contributing to this include the replacement of chloride containing sweat by water, and a "chloride shift" associated with intracellular acidosis From the practical point of view, the "error" in the find plasma composition is again no greater than that occus ring in the opposite sense in subjects receiving chloride containing fluids.

Metabolites Since blood sugar levels were sustained at least as well in the subjects drinking water as in thos that received "Erg" or special solution, there wouldo seem few metabolic advantages from drinking glucoses solutions over the marathon distance. Liver supplies off glycogen were plainly not exhausted, and the slight faf of average blood glucose figures from the mid-point to the end of the race ( $P<0.3)$ did not suggest that reserves were substantially depleted.

As in our previous studies, all subjects showed añ increase of blood urea, suggesting some protein breaks down. Since most subjects secreted some urine, it is nof possible to quantitate the protein breakdown; in the Boston marathon, we estimated this at less than 508 
$(200 \mathrm{Kcal})$. Although the rise of blood urea was a little greater in the water drinkers, we do not suggest the glucose solutions had any appreciable protein sparing effect since they did not elevate the blood glucose, nor were there significant differences of plasma creatine levels between water and glucose drinkers.

Enzymes The large increases of serum enzymes have been reported in other series of marathon runners, including our Boston and Hawaii contestants. However, it is perhaps worth stressing that this effect of recent vigorous exercise could lead to an erroneous diagnosis of myocardial infarction in a middle-aged patient, particularly if there is a history of some previous ischaemic heart disease.

Choice of fluid for the athlete The American College of Sports Medicine has recently published a "positionpaper" recommending that replacement fluids for the marathon runner contain less than $2.5 \mathrm{~g} / 100 \mathrm{ml}$ of glucose, less than $20 \mathrm{mE}$ of $\mathrm{Na}^{+}$, and less than $5 \mathrm{mE} \mathrm{K}^{+}$. The present paper, while not contradicting this recommendation, suggests there may be much in favour of the use of plain water. Specifically: (a) Glucose solutions are not necessary to sustain blood glucose levels - indeed, by slowing gastric emptying and possibly also by sparing body glycogen reserves, they may encourage dehydration, leading to a poorer relative performance than that attained by water drinkers.

(b) Potassium ions are not needed to sustain serum potassium levels during a race (although they may have value in the recovery period when muscle potassium reserves are being replenished). Like glucose, potassium ions also have an adverse effect on gastric emptying.

(c) Sodium ions are not needed during a race; indeed, the most normal levels of serum $\mathrm{Na}^{+}$are seen in subjects drinking water.

\section{ACKNOWLEDGEMENTS:}

The work of this laboratory is supported in part by Provincial Grants $965802 \mathrm{~J}$ and 263 . Our thanks are due to Johanna Kennedy, R.N., for programme coordination, and S. Qureshi for careful technical assistance.

\section{REFERENCES}

Åstrand, P. O. \& Saltin, B., 1964. Plasma and Red Cell Volume after Prolonged Severe Exercise. J.Appl.Physiol. 19, 829-832.

Bagby, G. T. \& Gollnick, P. D., 1975. The Role of Blood-Borne Carbohydrates in Exercise Metabolism, Med.Sci.Sports.

Campbell, J. M. H., Mitchell, M. B. \& Powell, A. T. W., 1928. The Influence of Exercise on Digestion. Guy's Hosp.Rept. 78, 279-293.

Costill, D. L., 1972. Fluid Replacement During and Following Exercise. In: Physiology of Fitness and Exercise. Ed. Alexander, J. F., Serfass, R. C. \& Tipton, C. M., Chicago: Athletic Institute.

Costill, D. L., Branam, L., Eddy, D. \& Fink, W., 1974. Alterations in Red Cell Volume Following Exercise and Dehydration. J.Appl.Physiol. 37, 912-916.

Costill, D. L., Coté, R., Miller, E., Miller, T. \& Wynder, S., 1975. Water and Electrolyte Replacement during Repeated Days of Work in the Heat. Med.Sci.Sports, 7, 79.

Dressendorfer, R. H. \& Scaff, J. H., Cardio-Respiratory Responses to Marathon Running in Cardiac Patients. Med.Sci.Sports. In press.

Fenn, W. O., 1939. The Deposition of Potassium and Phosphate with Glycogen in Rat Livers. J.Biol.Chem. 128, 297-307.

Fordtran, J. S. \& Saltin, B., 1967. Gastric Emptying and Intestinal Absorption during Prolonged Exercise. J.Appl.Physiol. 23, 331-335.

Hellebrandt, F. A. \& Tepper, R. H., 1934. Studies on the Influence of Exercise on the Digestive Work of the Stomach. Amer.J.Physiol. 107, 355-363. 
Hunt, J. N., 1961. The Osmotic Control of Gastric Emptying. Gastroenterology, 41, 49-51.

Hunt, J. N. \& Pathak, J. D., 1960. The Osmotic Effects of some Simple Molecules and lons on Gastric Emptyingि. J.Physiol.(Lond.) 154, 254-269.

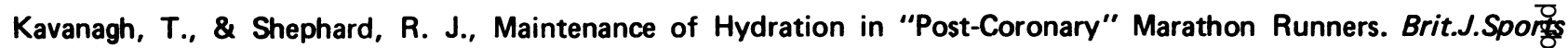
Medicine, 9, 130-135, 1976.

Kavanagh, T., Shephard, R. J. \& Pandit, V., 1974. Marathon Running after Myocardial Infarction. J.Amer.Med.Asso 229, (12), 1602-1605.

Kozlowski, S. \& Saltin, B., 1964. Effects of Sweat Loss on Body Fluids. J.Appl.Physiol. 19, 1119-1124.

Shephard, R. J., 1969. A Nomogram to Calculate the Oxygen Cost of Running at Slow Speeds. J.Sport Med.Phys. Fitness 9, 10-16.

Van Handel, P. J., Branam, G., Costill, D. L. \& Fink, W., 1975. Utilization of Exogenous Glucose during Enduranee Exercise. Med.Sci.Sports, 7, 87.

Wyndham, C. H. \& Strydom, N. B., 1972. Körperliche Arbeit bei hoher Temperatur; In: Zentrale Themen de्r Sportmedizin; Springer Verlag Berlin. 